University of Finance and Management

Warsaw

DANUTA ZAWADZKA

Institute of Agricultural and Food Economics

- National Research Institute

Warsaw

\title{
PROFITABILITY COEFFICIENT OF PIG PRODUCTION - ANALYTICAL AND EMPIRICAL ANALYSIS FOR THE PERIOD BETWEEN 2001 AND 2016
}

\begin{abstract}
This paper aims at morphological analysis of the profitability coefficient of pig production, which consists of two coefficients, i.e. production efficiency (grazing efficiency) and the relation of product prices (price of live pigs) to input prices (feed price). The profitability coefficient was, thus, presented in an analytical perspective and its components were illustrated empirically. The analisis of the profitability coefficient was based on two basic assumptions. The first is that efficiency is or should be the main source or basis of profitability of pig production. The second is that efficiency should compensate for or neutralize the negative effect of the deteriorating relation of live pig prices to feed prices on profitability. The empirical verification did not confirm the second assumption, which means that in the case of profitability of pig production, better efficiency does not neutralize the unfavourable impact of downward trend in the relation of pig prices to feed prices on the coefficient (market specificity in the researched years). The profitability coefficient and its components presented at the analytical level may become an important diagnostic basis for analysts of other agricultural markets.
\end{abstract}

Keywords: profitability, efficiency, live pigs, price relations.

JEL codes: Q13, Q11, D00, O12. 


\section{Introduction}

This article presents generally understood mutual relations between profitability of production and its effectiveness and the ratio of prices received to prices paid (which is treated as the source of profitability). The authors illustrate this on the example of the relation between profitability of production and effectiveness of the use of feed, and the relation of live animals' prices to prices of feeds. The article focuses primarily on cognitive issues and on verification of specific assumptions, and not on the analysis of profitability itself in the convention of market analysis, e.g. for the needs of a policy. In order to achieve the envisaged objective, the authors focus on the dependency between the profitability coefficient, effectiveness coefficient and the ratio of live animals prices to prices of feeds. The latter are treated as a component of the profitability coefficient ${ }^{1}$. Thus, the focus has been on its morphology, rather than on an analysis of a given condition, i.e. the profitability level. The article presents the issue from the point of view of microeconomics, where the deductive approach dominates. With such approach, no specific hypotheses have been proposed, only specific assumptions have been made. As pointed out, the significance of such approach is primarily cognitive and general. Nevertheless, it may also lead to conclusions serving a more long-term oriented policy.

The article argues, in a proprietary and analytical manner, that the production profitability coefficient, in fact, consists of two coefficients, i.e. effectiveness of production (grazing effectiveness) and the ratio of product prices (prices of live pigs) to prices of inputs (prices of feed) ${ }^{2}$. Driven by praxeological premise of rationality, it was assumed that effectiveness is or should be the primary source or foundation shaping profitability of pig production, particularly in the light of permanently deteriorating relation of live animal prices to prices of feed. The most important assumption of the article and its specific hypothesis is that effectiveness should compensate or neutralise the negative impact of deteriorating ratio of live pig prices to feed prices on profitability. Empirical analysis of the ratio, contributing to profitability of live pig production, gives sufficient grounds for assessment of its rationality, which could be a starting point for further inquiries based on understanding of the fundamental mechanism or morphology of profitability. Production profitability coefficient decomposed into its components is an important diagnostic basis for market analysts and policies implemented. The reasoning could be transferred to other agricultural products and their markets. The article does not refer to global literature, as the problem set in this manner is absent from it.

\footnotetext{
${ }^{1}$ Only industrial feeds was used for calculations, as they allow determination of their part produced only for pigs. Other feeds require estimates, not always correct. The reason for taking such decision was that from the point of view of morphology of the presented profitability coefficient it did not matter.

${ }^{2}$ This relation is connected to the notion and understanding of price scissors.
} 


\section{Production profitability coefficient in an analytical approach}

The problem of mutual relations between effectiveness and profitability of production is, of course, connected with balance and choice of a producer ${ }^{3}$. On the surface of the phenomena and from the point of view of market analysis, the problem manifests itself in the coefficient or at the level of production profitability. This could be expressed in the following way:

$$
o p=\left(y \cdot p_{y}\right) /\left(x \cdot p_{x}\right)
$$

or

$$
\mathrm{op}^{`}=y \cdot p_{y}-x \cdot p_{x}
$$

where:

$y \cdot p_{y}-$ revenue as a product of production volume (supply) and sales prices received for live animals,

$x \cdot p_{x}-$ cost of used (consumed) feed as a product of consumption volume and price paid for purchasing them.

Of course, when the coefficient op $>1$, the assessment is positive, same as when op' $>0$.

Coefficient $(o p)$, for the purpose of analysis of the problem posed, may be presented separately as an index of effectiveness and price relations (price scissors), which gives:

$$
o p=(e f) \cdot\left(p_{y x}\right)
$$

where:

$e f=y / x-$ production effectiveness, here as effectiveness measured through production volume per volume of appropriate feeds consumed (grazing effectiveness),

$p_{y x}=p_{y} / p_{x}-$ relation of the price received for live animals to the price paid for consumed appropriate feed.

The above indicates that profitability of production is in fact an issue of two coefficients: effectiveness and price relations ${ }^{4}$, i.e.:

\footnotetext{
${ }^{3}$ A producer achieves a balance in the sense of maximisation of his function of objective, when extreme revenue from a given input is at least equal to the cost of application of outlay of a given input, and in the base, when productivity of a given input is equal to its remuneration, see: Rembisz and Sielska (2015).

${ }^{4}$ In relation to each other they may exist in a substitutional or complementary arrangement, depending on the balance on the market for live animals, to which we shall return in the further part of this study. In conditions of a market with competitive balance and low demand flexibility, substitutional dependency should rather be expected, because prices of live animals shall in principle be arranged horizontally, while prices of feeds shall - by the nature of things - increase, thus deterioration of the relation of prices received to prices paid should be accompanied by an increased production effectiveness; we shall come back to this in the main text.
} 


$$
e f=y / x
$$

oraz:

$$
p_{y x}=p_{y} / p_{x}
$$

In the context of the problem posed, the volumes themselves are not crucial, but rather the relations or gaps between them, i.e. between production and feeds used, as well as relations between prices of live animals and prices of feed. Profitability is decided by directions of their mutual changes (ranges).

With this in mind, it is important to relate production and feeds used to each other, as well as their prices, whether expressed as levels or rates of changes 5 . One could, for example, make hypothetical assumptions on shaping of these values in a graphical manner ${ }^{6}$.

a)

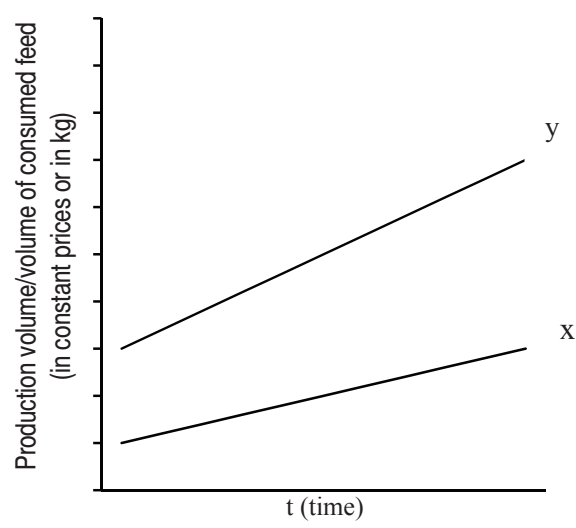

b)

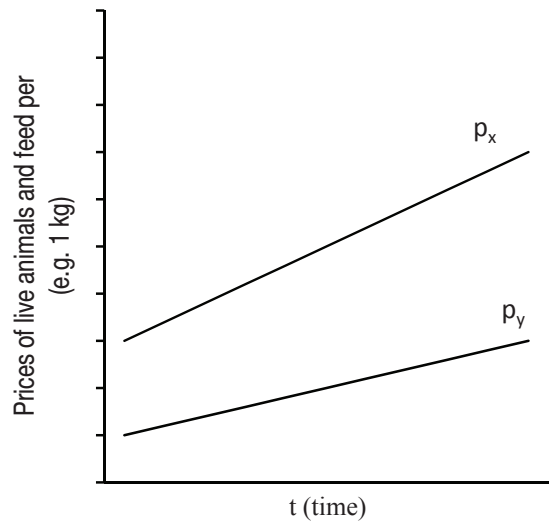

Fig. 1. Hypothetical assumptions on shaping the relations between production, outlay, and product prices and outlay.

Source: own study.

Of course, improvement of production effectiveness (improved grazing effectiveness) should correspond to this.

${ }^{5}$ E.g. the coefficient of effectiveness in rates of changes (following conversion to logarithm and calculation of first derivatives of time) could be presented as:

$$
\frac{\partial e f}{e f}=\frac{\partial y}{y}-\frac{\partial x}{x}
$$

Similarly, rates of price changes of live animals and feeds:

$$
\frac{\partial p_{y x}}{p_{y x}}=\frac{\partial p_{y}}{p_{y}}-\frac{\partial p_{x}}{p_{x}}
$$

${ }^{6}$ Irrespective of different dimensionality of shown values omitted in these figures. 


\section{Empirical illustration of components of production profitability}

The above simple findings could also be illustrated graphically with relevant diagrammes from empirical data. This shall be the starting point for further analysis. The figures below are presented in the convention of analytical formulas (3a) and (3b) derived above.

\section{Empirical illustration of production effectiveness coefficient}

Empirical foundations for shaping of effectiveness of production (grazing): $e f=y / x$ are presented in Figure 2. When graphically presenting the improvement of production effectiveness (grazing effectiveness) in ceteris paribus, one should expect that outlines (trend lines) of level of production of live pigs and feed consumption shall diverge. Instead, we have a picture where trend lines of outcome and outlay are convergent. Thus, there is only one conclusion - production (grazing) effectiveness decreases, when the basis for reference for production are consumed industrial feeds (as a clear and measurable purchased outlay, thus a good denominator for the coefficient in question ${ }^{7}$ ). It is a relatively long-term tendency, irrespective of short-term departures.

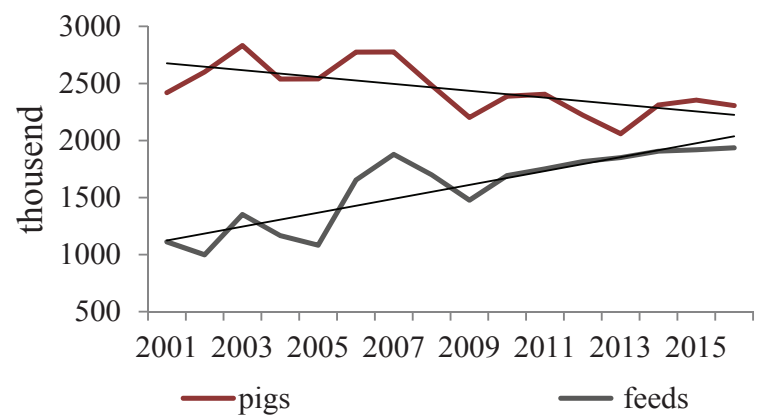

Fig. 2. Live pig production and production of industrial feeds for pigs.

Source: own calculations based on GUS data.

Of course, the above observations find expression in the tendency for decrease of production effectiveness shown below. It is an observation referring to the entire market, it does not necessarily have to be true, if we take into account perspectives of individual producers or groups for selected sub-periods. However, the article analyses only basic tendencies in the convention of adopted analytical premises (formulated equations) and from the perspective of microeconomics.

\footnotetext{
${ }^{7}$ Production referred to all feeds used for production of pigs, and not only to the industrial mix for pigs for fattening, which is a part of them, would most probably differ in terms of the inclination of the trend line (flatter line), and as result also in terms of inclination of the trend line of grazing effectiveness. However, absence of the possibility to separate the total volume of cereals used for feeding pigs does not allow for such analysis. Nevertheless, according to the authors these are issues for detailed market analysis for the purpose of a policy, and not solely for cognitive purposes, as in this analysis.
} 


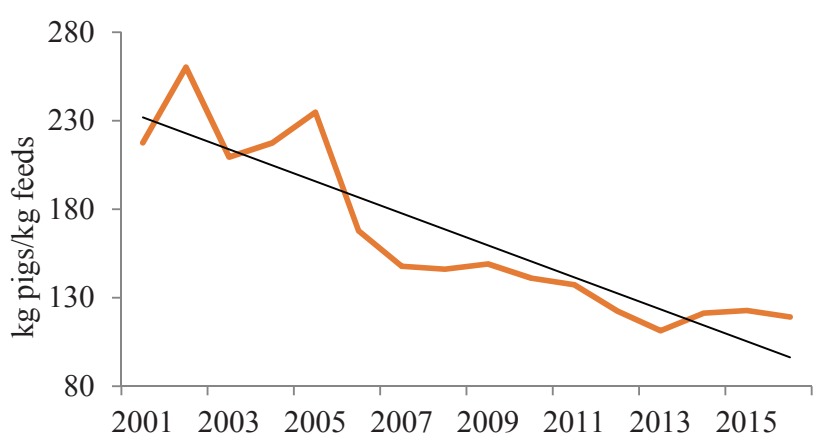

Fig. 3. Production (grazing) effectiveness expressed through the volume of live pig production per consumed industrial feeds for pigs.

Source: own calculations based on GUS data.

In line with the convention applied in equations (3) and (3b), the second component of profitability coefficient is the mutual relation referring to the tendency, prices of pigs and prices of industrial feeds.

\section{Empirical illustration of the coefficient of relation of price of pigs to price of feeds}

Empirical illustration of the coefficient of relation of price of pigs to price of feeds was shown in Figures 4 and 5 below, which have been presented separately in order to achieve clearer graphical representation of tendencies and because of the absence of direct comparability between them.

Irrespective of short-term volatility, the tendency of increasing pig prices is clear. This does not mean, however, in the sense of competitive balance, that producers were set against prices falling into a horizontal line in the tendency ${ }^{8}$. In fact, this means rather soft budgetary limitations and the possibility to improve or reinstate profitability of production through an expected increase in purchasing prices, irrespective of the course of periodic changes in this respect.

However, these potential opportunities must be confronted with prices of feeds, in line with the convention applied in equation (3b). Visualisation of empirical data referring to prices of feeds results in the tendency of changes shown below ${ }^{9}$.

\footnotetext{
${ }^{8}$ This would mean a very strong compulsion for increasing effectiveness as the sole source of increasing profitability of production.

${ }^{9}$ In this case, it is admissible to only take into account industrial feeds for pigs, as the share of feedstock in feed mixes in the total volume of cereals intended for feeds continues to increase. Thus, the share of industrial feeds in grazing structure increases. In case of pig farming, this is primarily the result of growing concentration. Large farms feed pigs primarily with industrial feeds. Thus, one could think that the volume of feeds have not been subject to major changes over time, only their structure has changed. Smaller farms are affected to a lesser degree, which was discussed in the further part of the paper. Also in more detailed approaches, in order to more fully illustrate production effectiveness, references were made to selected feed cereals.
} 


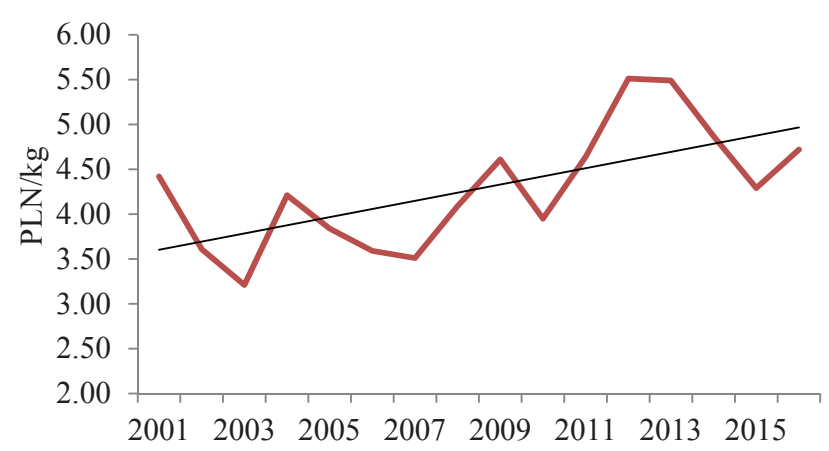

Fig. 4. Buying-in prices of live pigs.

Source: own calculations based on GUS data.

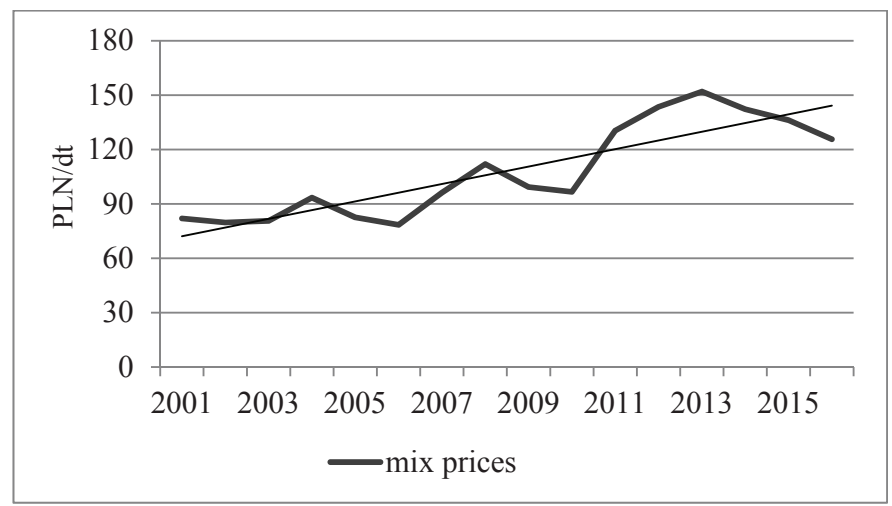

Fig. 5. Retail prices of mix for pigs for fattening.

Source: own calculations based on GUS data.

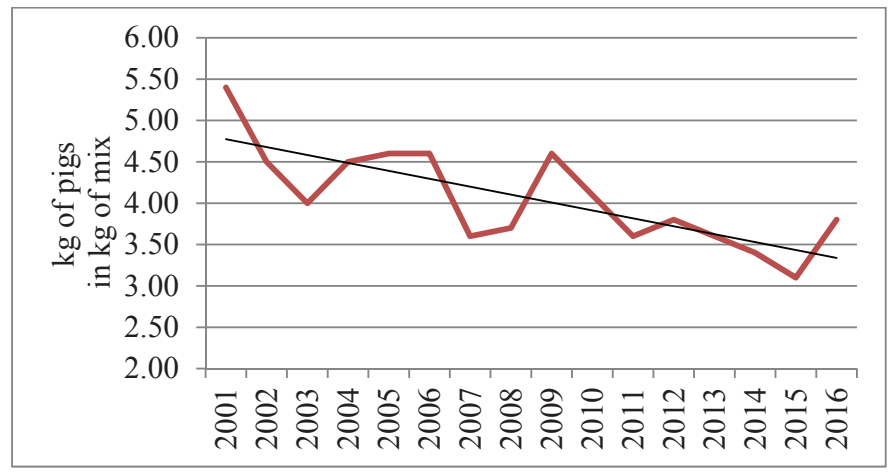

Fig. 6. The relation of buying-in prices of pigs to retail prices of mix for pigs for fattening. Source: own calculations based on GUS data. 
As shown in Figure 5, the upward trend is obvious. The above may suggest that the presented upward trend of prices of live pigs could have a compensatory nature, but it could be the reverse - the increase of feed prices could follow the increase of pig prices. This, however, is not the key issue for our analysis. What is important, in the convention applied in $(3 \mathrm{~b})$, are the mutual relations of trends when it comes to the course of both prices. This was shown in Figure 6.

The analysis of trends in this Figure shows that the relation of analysed prices (exogenous for produces in its nature) deteriorated, i.e. changed unfavourably for the profitability coefficient of pig production ${ }^{10}$. One could assume that this is a rather permanent and natural trend, in line with patterns, such as limited increase of demand for live pigs (Engel's law, high level of saturation of consumption, change of nutrition patterns and trends) and the increase of prices of the primary raw material for production of feeds - cereals. This imposes requirements for improved production effectiveness, as the source for compensation of this trend.

\section{Relations of effectiveness and prices to production profitability - analytical approach}

Returning to equation (3), i.e. $o p=(e f) \cdot\left(p_{y x}\right)$, we can define mutual relations between profitability and effectiveness of production and relations of product prices to feed prices, as its source. Taking production profitability as the resulting data (implice constant), the following correlation was found ${ }^{11}$ :

$$
\frac{e f}{o p}+\frac{p_{y x}}{o p}=1
$$

The above defines the role of effectiveness and price relations as sources of production profitability. It has a more flexible dimension. However, to understand the mechanism of profitability, it is more important to the grasp implications between these two sources of profitability of production (of live animals). Assuming that the price of live pigs, as an exogenous variable for an agricultural producer and in line with the market mechanism, is a function of their rarity, that is the volume of their supply for a given demand, we arrive at:

$$
p_{y}=\frac{1}{y}
$$

${ }^{10}$ Looking at the above problem in a more detailed manner, for the purpose of practical rather than
cognitive analysis, one sees that in the period under research (2001-2016) the buying-in prices of live
pigs were increasing at a much slower pace than prices of cereals and industrial feeds. If we take 2001
as a benchmark, then in 2016 prices of live pigs were higher by $7 \%$, prices of rye and barley by ca. $30 \%$,
and prices of mix for pigs for fattening by $53 \%$. Relations of prices of pigs to prices of cereals and feeds
were 20-30\% higher than in the first years of the period under research.

${ }^{11}$ The foundation here is conversion to logarithm. Starting from:

after conversion to logarithm, we arrived at:

$$
o p=\frac{y \cdot p_{y}}{x \cdot p_{x}}
$$

$$
\operatorname{lnop}=(\ln y-\ln x)+\left(\ln p_{y}-\ln \mathrm{p}_{\mathrm{x}}\right)
$$


The same is observed for the price of feed (in the same way as an exogenous variable for an agricultural producer), where we arrive at:

$$
p_{x}=\frac{1}{x}
$$

These market patterns represented analytically mean that high supply of live pigs (also in relation to feeds) means low prices and the reverse, with constant demand $^{12}$. Thus, on the basis of the above assumption and following certain conversions, we arrive at:

$$
\frac{y}{x} \Leftarrow \frac{p_{y}}{p_{x}}
$$

The above means that relations of price of live animals to the price of feed (as above), resulting from the degree of rarity (balance in the market for live animals and feeds defined primarily by their supply volumes, imply the level of production effectiveness (effectiveness of grazing in this case) ${ }^{13}$. It is, in fact, in line with fundamental assumptions on rational choices of a producer maximising his function of objective, to which reference was made at the beginning (see footnote 2), namely: extreme productivity of a given outlay (feed) at a given price of product (live) animals should equal the price of this outlay set exogenously for a given producer. Moreover, with the assumption that these are the costs that are adapted to prices of products, and not the market prices (buying-in price of live animals) to the cost of application of outlay (feeds), exogenously shaped price of feed should have an impact on grazing effectiveness ${ }^{14}$. From balanced conditions of a producer we arrive at:

$$
\frac{\partial y}{\partial x} \cdot p_{y} \Leftarrow p_{x}
$$

Therefore, one should expect the following graphical illustration of a hypothetical relation between effectiveness and the ratio of prices of live animals to feed prices:

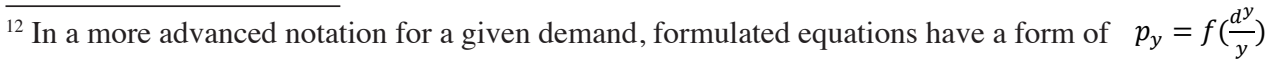
and $p_{x}=f\left(\frac{d^{x}}{x}\right) g$; where: $d$ means given demand for live pigs $(y)$ or demand for industrial feeds $(x)$.

${ }^{13}$ Of course one could imagine that it is also admissible to have a two-way implication or that effectiveness of grazing affects changes in relation of the price of live animals to feed prices, i.e.: $\frac{y}{x} \Leftrightarrow \frac{p_{y}}{p_{x}}$ and $\frac{y}{x} \Rightarrow \frac{p_{y}}{p_{x}}$ It is a process, which is by all means rational and connected to the essence of the market regulating mechanism.

${ }^{14}$ However, the above considerations were omitted in this paper, as they are related to a long term, in which result of technical and biological progress may emerge, connected with investments and changes in manufacturing technologies.
} 


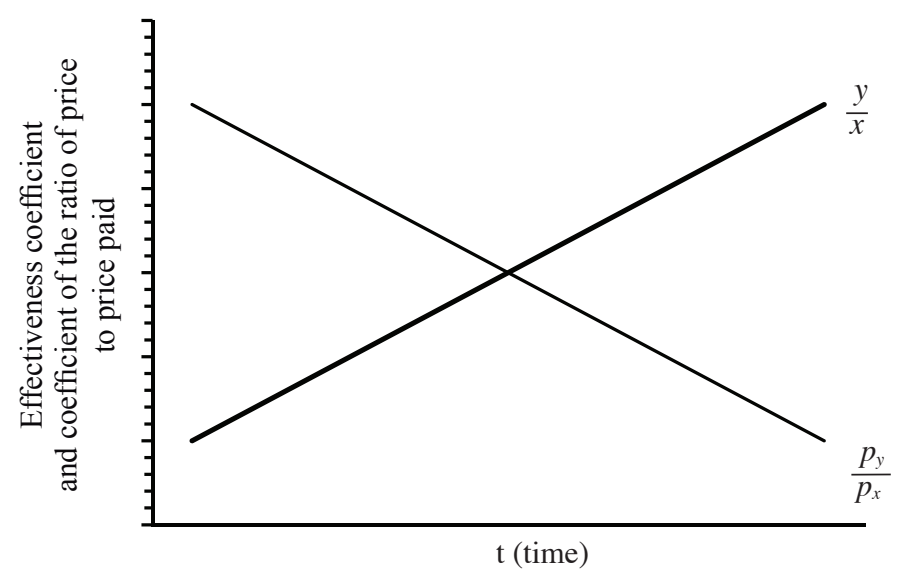

Fig. 7. The hypothetical assumption of compensation between effectiveness and price ratio between received and paid prices.

Source: own study.

The above has the nature of a certain hypothesis, which could be verified empirically.

This could also be a basis for an assumption that production profitability shall at least not decrease ${ }^{15}$ :

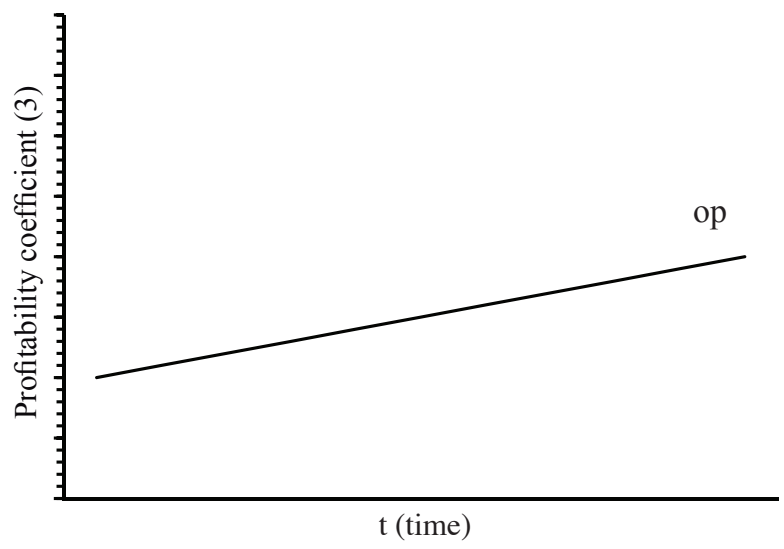

Fig. 8. Hypothetical course of profitability coefficient.

Source: own study.

${ }^{15}$ Such hypothetical assumption could be justified, as one could assume that:

$$
\left\{\frac{\partial y}{y}-\frac{\partial x}{x}\right\} \geq\left\{\frac{\partial p_{y}}{p_{y}}-\frac{\partial p_{x}}{p_{x}}\right\}
$$

The above means that a positive effect of improved production (grazing) effectiveness compensates for the negative effect in change of the ratio of prices received to prices paid. 


\section{Empirical illustration of relations of effectiveness and prices to production profitability}

Empirical and statistical demonstration of the above dependencies (4)-(8) is difficult. Below, graphical representations were shown, illustrating or even verifying this approach. The coefficient of correlation between profitability and grazing effectiveness calculated for 2001-2016 according to formula (3) amounts to: $\mathrm{R}=0.97$ and points to a connection between these two coefficients. This confirms the assumptions adopted, particularly in initial equations. The correlation between profitability and price relations (live animals: mix for pigs for fattening), calculated in the same way, amounts to $\mathrm{R}=0.87$. This also points to greater influence of effectiveness than price relations on the production profitability coefficient. However, this does not decide whether, in line with the reasoning and the figure above, changes in relations of prices of live animals to feed prices imply changes of effectiveness. Unfortunately, the analysis of the above figure, where trends in changes of effectiveness and price relations are shown, does not confirm these assumptions or the hypothesis adopted.

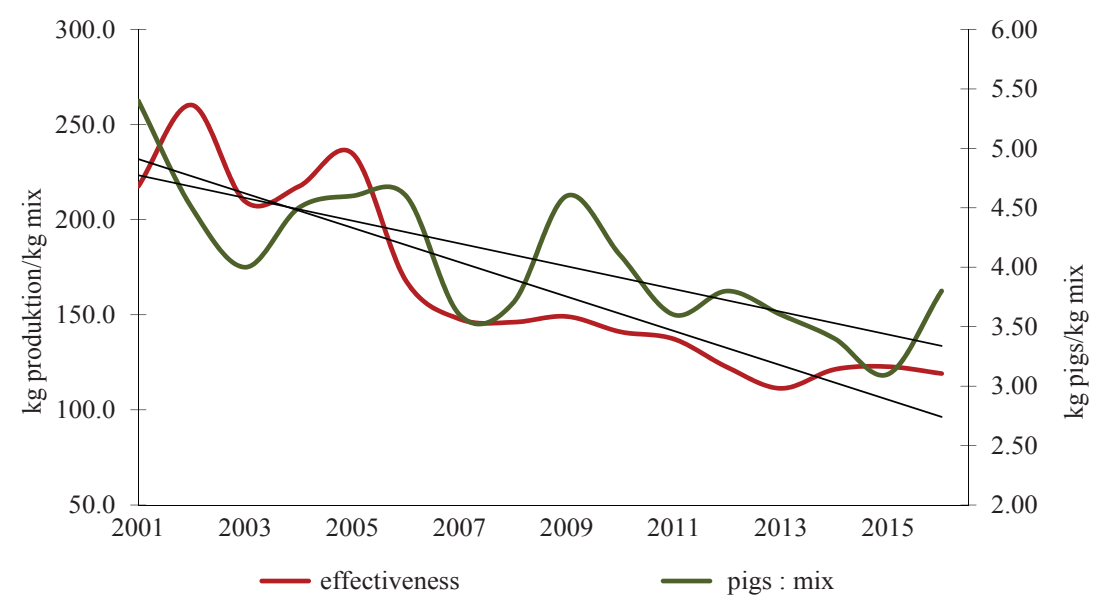

Fig. 9. Grazing effectiveness (in $\mathrm{kg}$ of pig production per $1 \mathrm{~kg}$ of industrial feed for pigs) and relations of pig prices to prices of mix for pigs for fattening.

Source: own study.

So we may ask: are the assumptions correct or excessively optimistic in their rationality and the hypothesis erroneous? Not really. This only means that in reality there is no neutralisation of an unfavourable trend in the relations of prices of live animals to feed prices through improved grazing effectiveness. As a result, we see decreasing profitability of production, as illustrated in Figure $10^{16}$.

\footnotetext{
${ }^{16}$ This is a verbatim graphical expression of equations (1) and (3), where profitability is a product of effectiveness and price relations identical to the ratio between revenue and costs for analysed values.
} 
The reasons behind this phenomenon are an issue of interpretation. One could obviously point to the absence of progress in the concentration processes or to the slowing down effect of payments and agricultural policy, including direct payments, mitigating the necessity to improve effectiveness. This - however is a topic to be discussed in a separate paper.

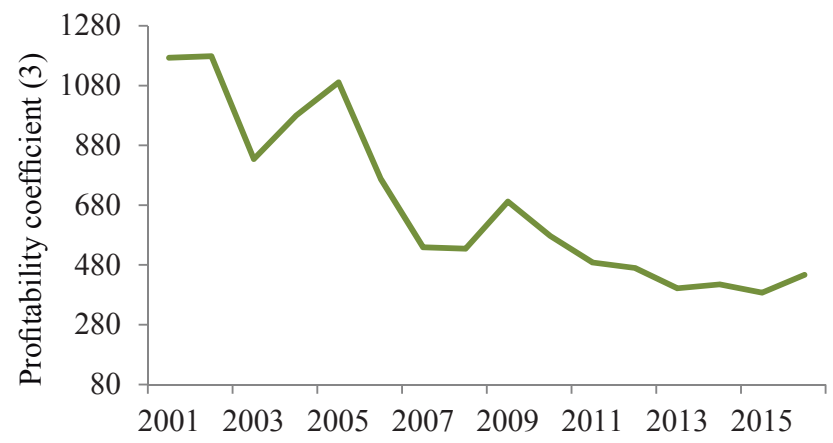

Fig. 10. Profitability of production of pigs.

Source: own calculations based on GUS data.

\section{Dynamics of changes in profitability and effectiveness and price relation in analytical and empirical approach}

Alongside the level of profitability and relation of this coefficient with effectiveness and analysed prices, an important role is played by the dynamics of changes of these values and their mutual relations. Starting with equation (3), we have arrived at its dynamic version, i.e. relevant rate of increase of production profitability, effectiveness and changes to price relations (price scissors), with the simplified result ${ }^{17}$ :

$$
r_{o p}=r_{e f}+r_{p_{y x}}
$$

where:

$r_{o p}=\frac{\partial o p}{o p} \cdot \frac{1}{t} \quad$ - rate of changes of production profitability,

$r_{e f}=\frac{\partial e f}{e f} \cdot \frac{1}{t} \quad-$ rate of changes of production effectiveness,

$r_{p_{y x}}=\frac{\partial p_{y x}}{p_{y x}} \cdot \frac{1}{t} \quad \begin{aligned} & \text { rate of changes of ratios of prices received to prices paid } \\ & \text { (price of live animals to prices of feed). }\end{aligned}$

\footnotetext{
${ }^{17}$ After converting to logarithm and calculation of derivatives (see footnote 5).
} 
This is important for market analysis and forecasting. It is a rational assumption for the increase of profitability to result from increased grazing effectiveness rather than from improved relations of live animal prices to feed prices. As assumed, the situation has the tendency to deteriorate, which was discussed before. This could be the basis for additional assumption, or even a hypothesis facilitating empirical verification, namely that the share of changes of effectiveness is larger than the impact changes in price relations have on shaping profitability of live pig production, thus looking as follows ${ }^{18}$ :

$$
\frac{r_{e f}}{r_{o p}}>\frac{r_{p_{y x}}}{p_{y x}}
$$

As previously, Figures 11 and 12 are empirical illustrations of these formulas.

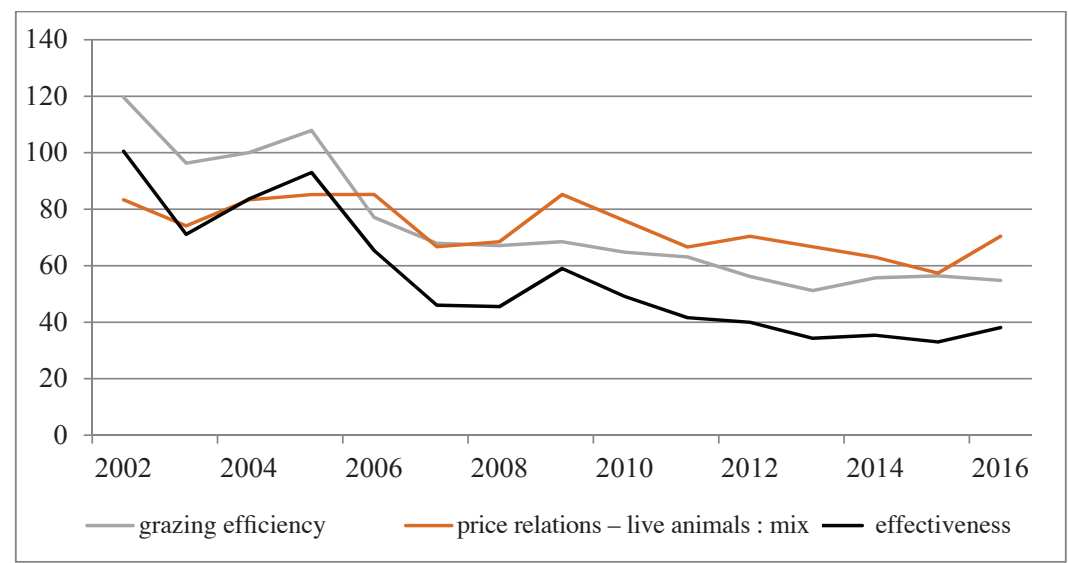

Fig. 11. Changes in profitability, effectiveness and price relations - live animals: mix for pigs for fattening $(2001=100)$.

Source: own calculations based on GUS data.

As seen, indicators referring to one-time base and included in formula (9) deteriorate in parallel. This is confirmed by correlation coefficients referred to above, as well as by calculations for sub-period 2001-2008, when production was increasing and in each subsequent year was higher than in 2001. The coefficient of correlation between profitability and effectiveness for this period amounted to $\mathrm{R}=0.94$, while the coefficient of correlation of profitability with price relations: $\mathrm{R}=0.85$. In 2008-2016, when production started to decrease, there was a strong correlation between changes of profitability, changes

${ }^{18}$ It is also possible to calculate indicators of structure, i.e. share of changes of effectiveness and price relations in shaping of the rate of change of production profitability:

$$
\frac{r_{e f}}{r_{o p}}+\frac{r_{p_{y x}}}{p_{y x}}=100 \%
$$


of effectiveness and changes of price relations, however, more with prices $\mathrm{R}=0.91$ and effectiveness $\mathrm{R}=0.87$ (for 2009-2016 $-\mathrm{R}=0.66$ for both indicators). Here, one could also make an observation, important from the policy perspective ${ }^{19}$, namely that in situations of decrease (crisis), the improvement of price relations has greater impact on production profitability than does improved effectiveness, while for growth the opposite is true. Deductively one could assume the reverse. Graphical illustration of formula (9) for rates of growth of rolling time delay of one year provides the following picture:

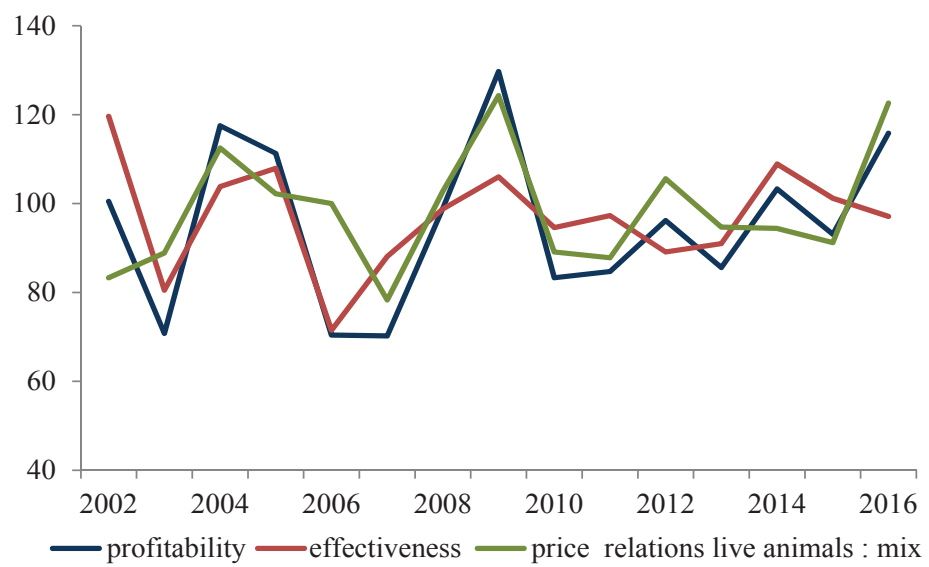

Fig. 12. Dynamics of profitability, effectiveness and price relations live animals: mix for pigs for fattening (previous year $=100$ ).

Source: own calculations based on GUS data.

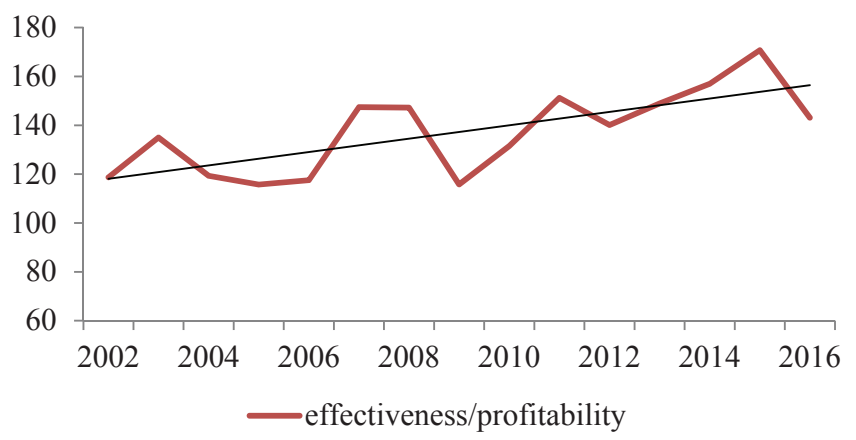

Fig. 13. Dynamics of changes of the relation of effectiveness to profitability $(2001=100)$.

Source: own calculations based on GUS data.

${ }^{19}$ This implies a different methodology. The conclusion was drawn from empirical observation, it was not confirmed whether the illustration was made from observation of deductive assumption resulting from formulated formula. 


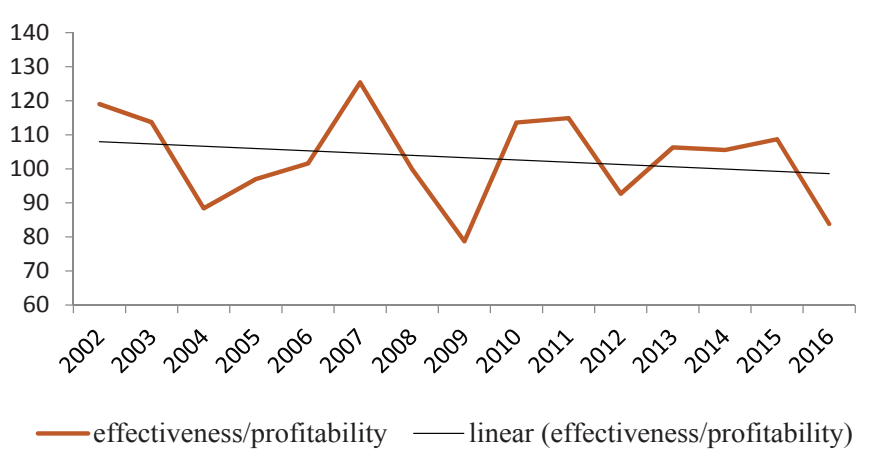

Fig. 14. Dynamics of changes of the relation of effectiveness to profitability (previous year=100).

Source: own calculations based on GUS data.

The above confirms earlier remarks on strong correlation of the analysed ratios of changes in profitability, effectiveness and price relations.

For possible confirmation of the assumption on rationality, the equation (10) was used, on the basis of which it was concluded that the share of improved effectiveness dominated over the share of improved price relations in shaping increased profitability. However, this assumption is correct for a relatively long period and one-base indices. Taking into account year on year changes, the share of improved effectiveness in improved profitability gets smaller and smaller. This is because in such case the role of improved price relations increases.

\section{Summary}

The paper analytically separates and empirically illustrates the components of production profitability coefficient, on the example of coefficient of production of live pigs.

The analysis of the profitability coefficient was carried out on the basis of two primary assumptions. Firstly, the effectiveness is or should be the primary source or foundation shaping the profitability of pig production. Secondly, the effectiveness should compensate or neutralise the negative impact that deteriorating ratio of live pig prices to feed prices has on profitability.

Empirical verification has not fully confirmed the adopted assumptions. For example, in reality there is no neutralisation of an unfavourable trend in relations of prices of live animals to feed prices through improved grazing effectiveness. This does not mean the assumption is wrong, but it is connected to current specificity of the market under research and the condition referring to production effectiveness.

The presented reasoning, structure, or in other words morphology of profitability coefficient, could be transferred to other agricultural products and their markets. The coefficient in question (with its components) could be of a universal nature and it could provide an important diagnostic base for market analysts and policies adopted. 


\section{References}

Bezat-Jarzębowska, A., Rembisz, W. (2016). Techniki wytwarzania jako endogenne uwarunkowania produkcji $i$ jej zmian $w$ rolnictwie krajów UE. Monografie Programu Wieloletniego 2015-2019, no. 32. Warsaw: IERiGŻ-PIB.

Rembisz, W., Sielska, A. (2015). Mikroekonomia współczesna. Warsaw: Vizja Press\&IT, 2015.

Rynek miesa. Stan i perspektywy. (2016). Analizy rynkowe, no. 50 and 51. Warsaw: IERiGŻ-PIB, ARR, MRiRW.

Rynek pasz. Stan i perspektywy. (2015). Analizy rynkowe, no. 37. Warsaw: IERiGŻ-PIB, ARR, MRiRW.

Rynek zbóż. Stan i perspektywy. (2014). Analizy rynkowe, no. 47. Warsaw: IERiGŻ-PIB, ARR, MRiRW.

Rynek zbóż. Stan i perspektywy. (2016). Analizy rynkowe, no. 50. Warsaw: IERiGŻ-PIB, ARR, MRiRW.

Zawadzka, D. (2013). Cykl świński a funkcjonowanie rynku żywca wieprzowego. $\mathrm{PhD}$ thesis, Warsaw: IERiGŻ-PIB.

Zawadzka, D. (2016). Rynek wieprzowiny. In: S. Stańko (ed.), Sytuacja na światowych rynkach mięsa i produktów mleczarskich oraz jej wpływ na rynek krajowy i możliwości jego rozwoju. Monografie Programu Wieloletniego 2015-2019, no. 31, (p. 40-78). Warsaw: IERiGŻ-PIB. 
WŁODZIMIERZ REMBISZ

Wyższa Szkoła Finansów i Zarządzania

Warszawa

DANUTA ZAWADZKA

Instytut Ekonomiki Rolnictwa i Gospodarki Żywnościowej

- Państwowy Instytut Badawczy

Warszawa

\title{
WSPÓŁCZYNNIK OPŁACALNOŚCI PRODUKCJI ŻYWCA WIEPRZOWEGO - UJECIE ANALITYCZNE I EMPIRYCZNE DLA OKRESU 2001-2016
}

\begin{abstract}
Abstrakt
Celem niniejszego artykułu jest analiza morfologiczna współczynnika opłacalności produkcji żywca wieprzowego, na który składaja sie dwa współczynniki, tj. efektywności produkcji (efektywność spasania) oraz relacji cen produktu (cen żywca wieprzowego) do cen nakładu (cen pasz). Wspótczynnik opłacalności został więc przedstawiony $w$ ujęciu analitycznym, a jego składowe zilustrowano empirycznie. Analize współczynnika opłacalności przeprowadzono w oparciu o dwa podstawowe założenia. Pierwsze, że efektywność jest lub powinna być głównym źródtem czy podstawa kształtujaca opłacalność produkcji trzody chlewnej. Drugie, że efektywność powinna kompensować czy neutralizować negatywny skutek dla opłacalności, pogarszajacej się relacji cen żywca do cen pasz. Empiryczna weryfikacja nie potwierdziła drugiego założenia, co oznacza, że w przypadku opłacalności produkcji żywca wieprzowego poprawa efektywności nie neutralizuje niekorzystnego wpływu na ten współczynnik niesprzyjajacej tendencji relacji cen żywca do cen pasz (specyfika rynku w badanych latach). Przedstawiony $w$ warstwie analitycznej wspótczynnik opłacalności oraz jego składowe moga stanowić ważna podstawę diagnostyczną dla analityków innych rynków rolnych.
\end{abstract}

Słowa kluczowe: opłacalność, efektywność, żywiec wieprzowy, relacje cen.

Accepted for print: 16.10.2017.

Unless stated otherwise all the materials on the website are available under the Creative Commons Attribution 3.0 Poland license. Some rights reserved to the Institute of Agricultural and Food Economics - National Research Institute.

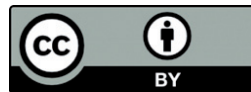

